\title{
Brucella canis
}

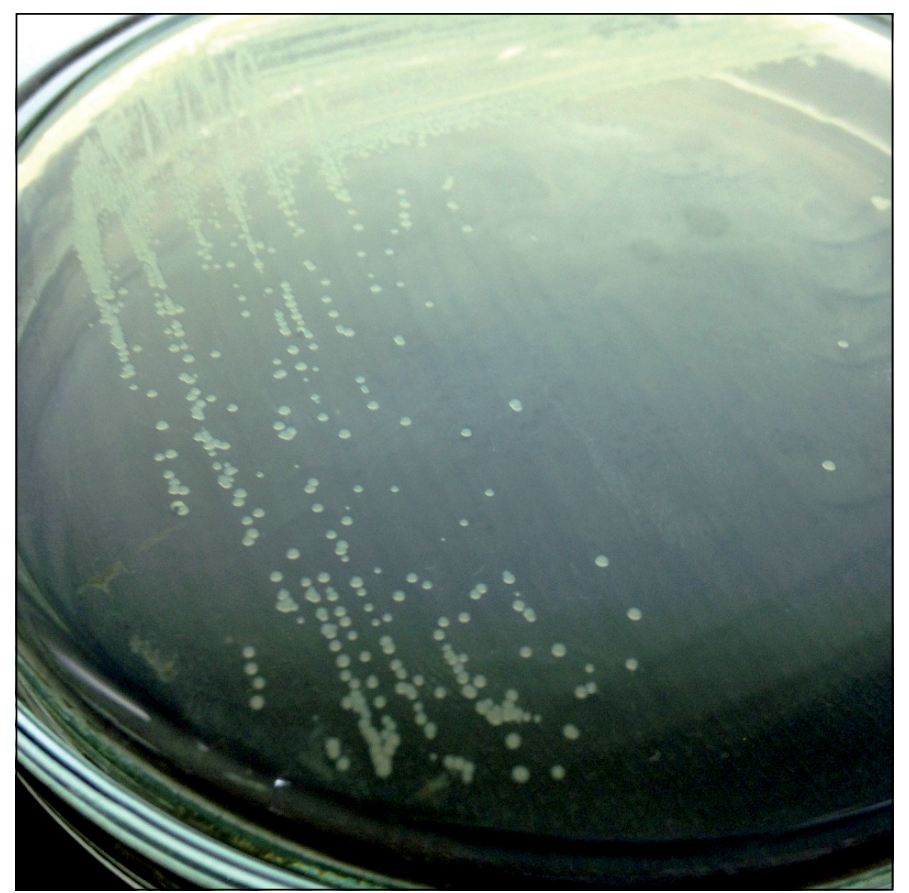

Figura 1. Colonias de Brucella canis en agar tripticasa soya con $5 \%$ de suero bovino, incubadas a $37^{\circ} \mathrm{C}$ por $72 \mathrm{~h}$. Se observan colonias pequeñas y traslúcidas. Cepa aislada de orina de un perro aparentemente sano. LBV-FAVET2014.

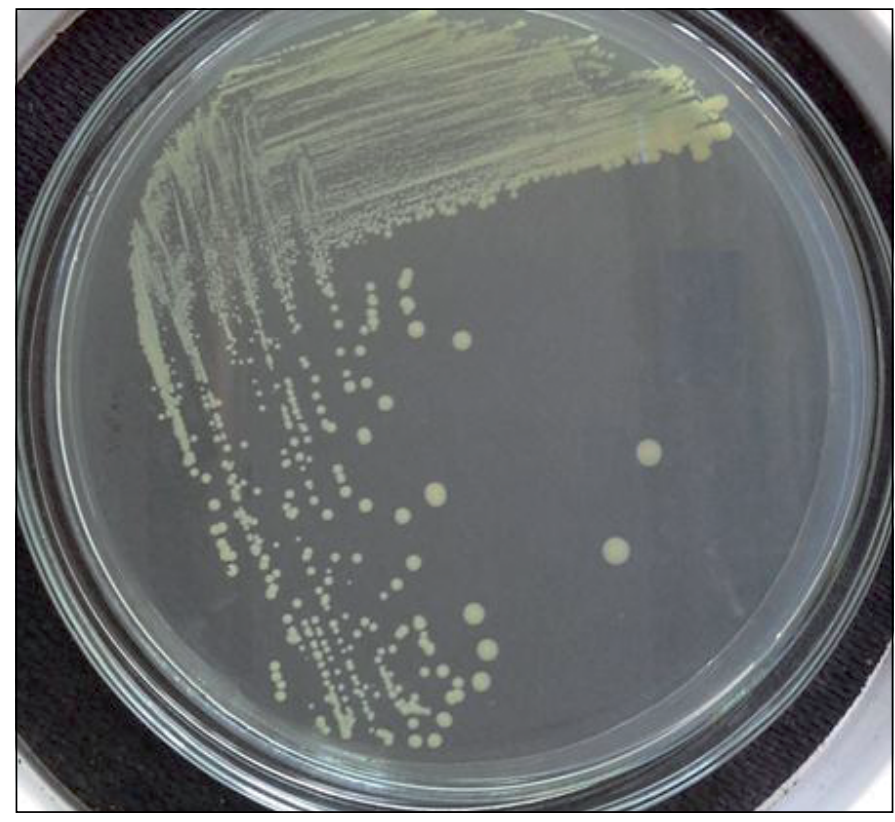

Figura 2. Colonias de Brucella canis en agar tripticasa soya con $5 \%$ de suero bovino, incubadas a $37^{\circ} \mathrm{C}$ por 6 días. Se observan colonias de mayor tamaño y opacas. LBV-FAVET2014. 


\title{
Brucella canis
}

Brucella canis se observa como pequeños cocobacilos gramnegativos, individuales o en cortas cadenas, inmóviles, de 0,5 a $0,7 \mu \mathrm{m}$ de diámetro y 0,6 a $1,5 \mu \mathrm{m}$ de largo, asporógenos, acapsulados y de vida intracelular facultativa. Su metabolismo es aeróbico, siendo catalasa y oxidasa positivas. La bacteria crece bien en medios enriquecidos que contengan peptonas o triptonas adicionadas con extracto de levaduras, suero o sangre. Existen medios comerciales como agar Brucella, agar SDA (Sabouraud-dextrosa), agar TSA, agar Farrell y agar Thayer Martin modificado, donde las colonias aparecen luego de $72 \mathrm{~h}$ de incubación aerobia a $37^{\circ} \mathrm{C}$, aunque pueden tardar más en aparecer. Las colonias inicialmente se observan pequeñas (1-5 mm), traslúcidas con un leve tono azulado, de bordes definidos y mucoides en el primer aislamiento. Con el transcurso de los días, las colonias se tornan opacas y de un mayor tamaño. En agar sangre de cordero no se observa hemólisis. El crecimiento en medios líquidos se caracteriza por presentar aspecto de cordón. Las tinciones recomendadas son la de Ziehl-Neelsen modificada (la bacteria se tiñe de color rojo) y la de Köster modificada (la bacteria se tiñe de color anaranjado), aunque la tinción de gram es suficiente.

Su crecimiento en medios con tionina pero no con fucsina básica (1:50.000) es una característica diferencial con las otras especies del género. No necesita $\mathrm{CO}_{2}$ para crecer, no produce $\mathrm{H}_{2} \mathrm{~S}$, produce rápidamente ureasa, suele reducir los nitratos. Oxida la D-ribosa, D-glucosa, L-arginina pero no la L-alanina, L-arabinosa ni L-galactosa. La oxidación del $i$-eritritol es variable. No es lisada por los fagos $\mathrm{Tb}, \mathrm{Fi}, \mathrm{Wb}$ o $\mathrm{Bk}_{2}$. No reacciona (precipita o aglutina) con los sueros anti-brucelas lisas. Desde un punto de vista estructural, B. canis se diferencia del resto de las especies por corresponder, junto a $B$. ovis, al grupo de las "brucellas rugosas", caracterizadas por su escasa cantidad o ausencia total del polisacárido O (PO) del LPS de la pared. La estructura del LPS del género Brucella presenta el lípido A formado por diferentes ácidos grasos, luego un núcleo central compuesto de 2-ceto-3-desoxioctulosónico, manosa, glucosa y quinovosamina y, finalmente un homopolímero de 4-formamido-4,6-didesoximanosa (perosamina) que se proyecta hacia el exterior y cuya conformación espacial permite reconocer los antígenos A y M. En el caso particular de las cepas rugosas (LPS-R), éstas carecen de la cadena de polisacáridos (PO) y de la quinovosamina del núcleo central del LPS, siendo esta la razón de no reaccionar con antisueros monoespecíficos para los antígenos A y M de la pared celular de cepas lisas (LPS-S de $B$. abortus, B. melitensis, B. suis). La presencia de LPS-R en B. canis no sólo le otorga la morfología mucoide a la colonia sino también diferencias fundamentales en su patogenia, comparada con las cepas lisas (B. abortus, B. melitensis, B. suis).

Para la identificación molecular del género Brucella, existen diferentes protocolos de RPC, mientras que para identificar y subtipificar B. canis se utilizan el qPCR (RPC cuantitativa), RPC multiplex y MLVA (Multiple loci VNTR analysis). Sin embargo, la interpretación de los resultados resulta dificultosa debido a la gran homogeneidad genética entre las especies particularmente con $B$. suis. Cabe destacar que hasta la fecha no existe validado un qPCR robusto y de fácil interpretación para la detección de $B$. canis.

\author{
Consuelo Borie y Nicolás Galarce \\ Laboratorio de Bacteriología Veterinaria \\ Departamento de Medicina Preventiva Animal \\ Facultad de Ciencias Veterinarias y Pecuarias. Universidad de Chile. \\ Programa Doctorado en Ciencias Silvoagropecuarias y Veterinarias.
}

Versión in extenso disponible en www.sochinf.cl

Correspondencia a: cborie@uchile.cl 